\title{
Evaluation of Resistance to Leaf Scald by Quantitative PCR of Xanthomonas albilineans in Sugarcane
}

A. Gutierrez, Department of Plant Pathology and Crop Physiology, Louisiana State University Agricultural Center, Baton Rouge 70803; F. F. Garces, Centro de Investigacion de la Cana de Azucar del Ecuador, CINCAE, Km 49.6 Vía Durán-Tambo, El Triunfo, Guayas, Ecuador; and J. W. Hoy, Department of Plant Pathology and Crop Physiology, Louisiana State University Agricultural Center

\begin{abstract}
Gutierrez, A., Garces, F. F., and Hoy, J. W. 2016. Evaluation of resistance to leaf scald by quantitative PCR of Xanthomonas albilineans in sugarcane. Plant Dis. 100:1331-1338.

Leaf scald, caused by Xanthomonas albilineans, is a major sugarcane disease controlled primarily with host resistance. Because visual evaluation can be uncertain due to erratic symptom expression, a reliable resistance screening method is needed. A quantitative polymerase chain reaction (qPCR) with potential for resistance screening was used to compare bacterial populations in 31 clones at different times after inoculation, and the correlation with the visual symptom rating method was determined. Comparisons of bacterial populations quantified by qPCR and visual symptom severity ratings in systemically infected leaves showed variable results, with the highest correlation at 8 weeks after inoculation.

To measure consistency, the correlation was determined among three different field experiments for data obtained with the same method at different times after inoculation. The qPCR assay was more consistent among experiments compared with visual symptom rating at 8 weeks after inoculation. Susceptible check cultivars always had high bacterial populations but the severe inoculation resulted in moderate to high bacterial populations in two of three resistant checks in some experiments. The results suggest that qPCR can provide an improved method to evaluate resistance to leaf scald in sugarcane; however, multiple experiments will be needed to accurately determine clone resistance levels.
\end{abstract}

Leaf scald is a major disease of sugarcane (interspecific hybrids of Saccharum L.) with worldwide distribution caused by Xanthomonas albilineans (Ashby) Dowson (Rott and Davis 2000). The disease can be a serious problem due to high losses in tons of cane per hectare and reduced juice quality (Hoy and Grisham 1994; Ricaud and Ryan 1989; Rott and Davis 2000). X. albilineans produces a host toxin, albicidin, and can cause three different phases of infection and symptomatology on sugarcane: latent (no symptoms), chronic, and acute (Ricaud and Ryan 1989; Rott and Davis 2000; Saumtally and Dookun 2004). Symptom expression and severity are associated with the level of cultivar resistance, environmental conditions, and pathogen aggressiveness.

The chronic phase is characterized by symptoms that vary in severity, including bleached or chlorotic longitudinal streaks along leaf veins termed "pencil lines", leaf chlorosis or bleaching, leaf necrosis, development of abnormal side shoots exhibiting symptoms on stalks, reddish discoloration of vascular bundles at the node level, stunting, wilting, and death (Ricaud and Ryan 1989; Rott and Davis 2000; Saumtally and Dookun 2004). The acute phase occurs as a sudden wilting of plants resulting in death, with little or no previous symptom expression. Large areas of a field planted with a highly susceptible cultivar may be affected in this manner following a period of drought stress (Ricaud and Ryan 1989; Rott and Davis 2000; Saumtally and Dookun 2004). The latent phase occurs and ends for reasons which are unknown (Rott and Davis 2000). Detection of the disease is difficult when infection is latent, and this resulted in worldwide spread of leaf scald during sugarcane germplasm exchanges.

Leaf scald was detected in Louisiana in 1992 (Hoy and Grisham 1994). Analyses of genetic variability conducted following the rapid spread of leaf scald in the Western Hemisphere demonstrated that $X$. albilineans isolates associated with the outbreak belonged to pulsed-field gel electrophoresis group B (Davis et al. 1997) and

Corresponding author: J. W. Hoy; E-mail: jhoy@agcenter.lsu.edu

Accepted for publication 7 February 2016.

http://dx.doi.org/10.1094/PDIS-09-15-1111-RE

(C) 2016 The American Phytopathological Society albicidin gene cluster restriction length polymorphism group B (Champoiseau et al. 2006), and they possessed a greater propensity for aerial transmission.

Host plant resistance is the most important leaf scald control method (Ricaud and Ryan 1989; Rott and Davis 2000). Resistance levels are based on visual ratings of the severity of systemic infection symptoms following inoculation (Koike 1965). The decapitation method, in which young shoots are cut above the apical meristem and bacterial inoculum is applied to the cut surface, is used for inoculation (Koike 1965). However, accurate evaluation of resistance levels in sugarcane clones is difficult because reactions obtained from field experiments are erratic. In addition, subjective rating systems based on symptom severity can be affected by variability among raters.

Resistance has been associated with the extent of bacterial colonization (Rott et al. 1994 1997). Disease severity and bacterial concentration in the shoot apex were found to be correlated (Rott et al. 1997). Susceptible cultivars were extensively colonized in the apex and lower part of the stalk, whereas $X$. albilineans populations in the shoot apex were low in cultivars considered resistant based on phenotype evaluation. These results suggested a method to accurately detect and compare bacterial populations in different sugarcane genotypes might provide an alternative method for resistance screening.

Previously, a quantitative polymerase chain reaction (qPCR) was developed which demonstrated potential for leaf scald resistance screening (Garces et al. 2014). SYBR Green and TaqMan qPCR assays were developed using primers from the bacterium-specific albicidin toxin gene cluster. The qPCR assays for $X$. albilineans detection were faster and more sensitive than conventional PCR (Garces et al. 2014). However, only six sugarcane cultivars with extreme reaction against the disease (three susceptible and three resistant) were compared. Therefore, additional research was needed to demonstrate the utility of this method for determining and comparing the resistance levels of larger clone populations in selection and resistance studies. The determination of the best time after inoculation to collect samples and the plant tissue best able to distinguish differences in bacterial populations among clones with variable resistance levels, a comparison of composite versus single-leaf sample collection, and, finally, the comparison of multiple qPCR results with the visual rating system were all study objectives, with the overall goal of 
determining whether $\mathrm{qPCR}$ can provide a more reliable alternative leaf scald resistance screening method.

\section{Materials and Methods}

Bacterial isolation. Bacteria were isolated from a longitudinal section of leaf with a pencil-line symptom. Tissue was surface sterilized with $\mathrm{NaOCl}(0.5 \%)$ for $30 \mathrm{~s}$ and rinsed with water. The leaf sections were dried, cut in small pieces, and placed in a 1.5-ml microcentrifuge tube (Eppendorf, Hauppauge, NY) containing $1 \mathrm{ml}$ of sterile distilled water. The tubes were incubated overnight at $4^{\circ} \mathrm{C}$. A loop of bacterial suspension was transferred to semiselective XAS medium with antibiotics (cephalexin at $25 \mathrm{mg} / \mathrm{liter}$, novobiocin at $30 \mathrm{mg} /$ liter, kasugamycin at $50 \mathrm{mg} / \mathrm{liter}$, cycloheximide at $100 \mathrm{mg} / \mathrm{liter}$, and benomyl at $2 \mathrm{mg} / \mathrm{liter}$ ) and incubated at $28^{\circ} \mathrm{C}$ (Davis et al. 1994). After 5 to 8 days, single colonies were selected and streaked to obtain pure cultures on solid XAS medium without antibiotics. Pure cultures were incubated at $28^{\circ} \mathrm{C}$ and, after $48 \mathrm{~h}$, $5 \mathrm{ml}$ of sterile water was added to each plate. The bacterial suspension was diluted to obtain $10^{8} \mathrm{CFU} / \mathrm{ml}$ based on spectrometric absorbance ( 0.18 optical density at $590 \mathrm{~nm}$ ). The bacterial suspension was used for standard curve construction in the $\mathrm{qPCR}$ and for inoculation of plants in the field.

Plant inoculation and experimental design. Plants were inoculated using the decapitation method by placing bacterial suspension with a sprayer on the surface previously cut above the apical meristem with scissors dipped in the inoculum suspension (Koike 1965). Twenty young plants with stem elongation just beginning were inoculated per clone, and the inoculations were done at the end of the day at about sunset. Field experiments were performed in summer 2011 and summer 2012. In summer 2011, inoculations were performed on 16 June and 1 July using the same sugarcane planting. The 2012 experiment was performed on 28 May. All field experiments were conducted at the Sugar Research Station of the Louisiana State University Agricultural Center at St. Gabriel. Individual clones were planted in single-row plots $6 \mathrm{~m}$ in length in a randomized design without replication.

Plant material and sample collection. Thirty-one sugarcane clones were included to compare quantification of $X$. albilineans by TaqMan qPCR and rating resistance based on symptom severity. The clones included three known leaf-scald-resistant clones (LCP 85-384, Ho 95-988, and HoCP 96-540) and two susceptible clones (HoCP 85-845 and HoCP 86-849) as checks. To determine the best source of tissue for distinguishing resistant and susceptible clones by qPCR, different plant tissues were sampled and compared. The base of the second youngest leaf above the youngest fully emerged leaf that is known as the top visible dewlap (TVD) leaf, designated as TVD-2, was collected at 8 and 12 weeks after inoculation (WAI). The leaf tissue was collected individually (one leaf per sample) or as a composite sample (three TVD-2 leaves from different plants per sample). Stem sections containing the apical meristem and the stem base were collected 12 WAI. Meristem and stem base samples were collected in plastic bags and leaf sections in 50-ml centrifuge tubes, then placed on ice and kept at $4{ }^{\circ} \mathrm{C}$ until processing in the laboratory. Between samples, scissors and shears were surface sterilized by dipping in $95 \%$ ethanol and flaming.

Leaf diffusates were obtained by immersion of 20 discs of tissue $6 \mathrm{~mm}$ in diameter in sterile distilled water overnight. Sap for the stem base tissue was collected by centrifugation of a small cylinder of stem tissue ( $1 \mathrm{~cm}$ in height and $0.8 \mathrm{~cm}$ in diameter) in $1.5-\mathrm{ml} \mathrm{micro-}$ centrifuge tubes. Leaf diffusates and sap samples were transferred to $1.5-\mathrm{ml}$ tubes and centrifuged at $9,000 \times g$ for $5 \mathrm{~min}$, the supernatant was discarded, and bacterial pellets were suspended in $100 \mu \mathrm{l}$ of lysis buffer $(0.05 \mathrm{M} \mathrm{KCl}, 0.01 \mathrm{M}$ Tris- $\mathrm{HCl}$, and $1 \%$ Tween 20, $\mathrm{pH} 8.3$ ). Genomic DNA for PCR was prepared by lysing the cells at 95 to $100^{\circ} \mathrm{C}$ for $15 \mathrm{~min}$ and immediately incubating the samples on ice for $10 \mathrm{~min}$ (Jacobs et al. 2008). The DNA from the meristem was extracted by macerating $100 \mathrm{mg}$ of tissue in a mortar containing $1.5 \mathrm{ml}$ of AP1 buffer from the Qiagen DNeasy Plant Mini Kit (Qiagen Inc., Valencia, CA), then following the manufacturer's instructions.
Disease evaluation. Disease severity was evaluated according to the type of symptoms observed in 12 to 18 inoculated stalks. In field experiments, all clones developed symptoms in the inoculated leaves, and it was not possible to distinguish variable resistance levels in different clones. Disease severity was assessed at 8 and $12 \mathrm{WAI}$ in intact leaves that emerged after inoculation. Visual symptoms were assessed for systemically infected leaves and rated using a 1-to-9 rating system, for which 1 to 3 would be considered resistant, 4 to 6 would be rated moderately susceptible, and 7 to 9 would be rated highly susceptible. The assessment was performed using the TVD-2 leaf, and the severity was evaluated for each clone using the formula $\mathrm{DS}=[(1 \times \mathrm{NS})+(3 \times \mathrm{PL})+(5 \times \mathrm{ML})+(7 \times \mathrm{N})+(9 \times \mathrm{D})] / \mathrm{T}$, where $\mathrm{NS}=$ number of stalks without symptoms; PL = number of stalks with the TVD-2 leaf exhibiting one or two narrow, white, pencilline streaks; $\mathrm{ML}=$ number of stalks with more than two pencilline streaks in leaves; $\mathrm{N}=$ number of stalks with leaf necrosis or bleaching; $\mathrm{D}=$ number of dead stalks or stalks with side shooting; and $\mathrm{T}=$ total number of stalks per clone.

TaqMan qPCR conditions. Previously, a set of primers was designed for TaqMan qPCR from the $X$. albilineans genome sequence using the program Beacon Designer (Premier Biosoft International, Palo Alto, CA) (Garces et al. 2014). The gene cluster of albicidin biosynthesis corresponding to the $a l b I$ gene (Royer et al. 2004) was targeted for $X$. albilineans-specific primers (Garces et al. 2014). A TaqMan Double-Quenched ProbeTM (5'FAM/ZEN/ $3^{\prime}$ ABkFQTM) with two quenchers (ZEN and ABkFQ) and the FAM reporter was developed following the manufacturer's instructions (IDT Integrated DNA Technologies, Skokie, IL).

From each sample of DNA, $2 \mu l$ was mixed with $10 \mu$ l of TaqMan universal master mix (Roche, Basel, Switzerland), $1 \mu$ l of each forward and reverse primers $(10 \mu \mathrm{M}), 1 \mu \mathrm{l}$ of TaqMan doublequenched probe XaQ ( $2 \mu \mathrm{M}$; IDT Integrated DNA Technologies), and $5 \mu \mathrm{l}$ of sterile distilled water for a final volume of $20 \mu \mathrm{l}$. The conditions of amplification were as follows: an initial step at $50^{\circ} \mathrm{C}$ for $10 \mathrm{~min}$, a second step of $95^{\circ} \mathrm{C}$ for $2 \mathrm{~min}$, followed by 35 cycles of DNA denaturation at $94^{\circ} \mathrm{C}$ for $15 \mathrm{~s}$ and annealingpolymerization at $60^{\circ} \mathrm{C}$ for $1 \mathrm{~min}$ (Garces et al. 2014).

Positive control samples for all PCR experiments were diffusates from leaves collected from plants showing symptoms of leaf scald that previously tested positive for X. albilineans. Negative control samples were diffusates from known noninfected plants. A no-template sample consisting of purified water was always included. All controls were added to the reaction plate in triplicate wells for all experiments. A standard curve was constructed using the same concentration of bacteria used for the inoculation in the field $\left(3.5 \times 10^{8} \mathrm{CFU} / \mathrm{ml}\right)$ with a five-dilution series to $3.5 \times 10^{4} \mathrm{CFU} / \mathrm{ml}$. The standard curve constructed from the dilution series was used for the determination of the $X$. albilineans concentration in the samples.

Data analysis. Bacterial populations were quantified by qPCR through introgression of the positive samples average on the standard curve determined by linear regression of the known $X$. albilineans concentration dilution series. The influence of the inoculation, the time after inoculation, the plant tissue source, and the sampling method on disease severity ratings and bacterial concentrations were analyzed using the Proc MIXED procedure of SAS (version 9.3; SAS Institute Inc., Cary, NC). For the analysis of variance (ANOVA) of the treatments, the bacterial concentration data were logarithmic transformed $\left(\log _{10}\right)$ to meet the normal distribution assumption of the ANOVA analysis. The normality was measured using the Shapiro-Wilk test and the Kolmogorov-Smirnov test using SAS software (version 9.3; SAS Institute Inc.). The transformation produced results among 1 to 9 assigned ratings, the same scale used for the visual rating of the disease severity. When the bacterial concentration was zero, a value of 1 was adopted for the transformed data.

For breeding program experiments to evaluate resistance, the focus is on determining accurate ratings for individual clones rather than relative clone comparisons. Resistant and susceptible checks are included in all experiments to assess the success of the inoculation and as an indicator of rating accuracy. The repeatability of clone reactions is an important determinant of the accuracy of ratings. 
Therefore, the two resistance evaluation methods (symptoms and bacterial populations) were evaluated individually and compared with each other with correlation analyses. The correlation between different experiments using the same method for resistance evaluation was compared using the Pearson correlation coefficient ( $r$ ), a coefficient used for data with an expected linear relationship. The visual disease severity ratings and the bacterial populations (calculated indirectly using TaqMan qPCR) were compared using the Spearman's rank correlation coefficient. The Spearman's rank correlation coefficient $(\rho)$ was used to compare two different methods without a clear linear relationship and different units of measure with a high difference in order of magnitude. The correlations were calculated for 8 and $12 \mathrm{WAI}$ in the three field experiments performed. All the statistical analyses were performed using SAS software (version 9.3; SAS Institute Inc.).

\section{Results}

Visual ratings of leaf scald resistance. To evaluate the influence of the time after inoculation in the assessment of the disease susceptibility based on symptomatology, two different times after inoculation ( 8 and $12 \mathrm{WAI}$ ) were tested in 31 different sugarcane clones in three different experiments performed in 2011 and 2012. The time after inoculation affected the results of the visual rating $(F=15.28$, $P<0.001)$. Also, there were significant differences among the three different experiments $(F=19.47, P<0.001)$, and the clones evaluated were distinguished based on symptoms resulting from inoculation of $X$. albilineans $(F=5.10, P<0.001)$. However, clone reaction did not show significant variation among experiments based on the interaction between the inoculations performed and the clones evaluated $(F=1.32, P=0.141)$, and clone reaction was not significantly affected by the time after inoculation when the symptoms were assessed $(F=0.94, P=0.566)$.

Leaf scald severity ratings varied across clones in the three experiments at 8 and $12 \mathrm{WAI}$ (Tables 1,2, and 3). The second inoculation performed in 2011 showed less severe symptoms across all clones at $8 \mathrm{WAI}$ compared with the other experiments, with ratings ranging from 1.0 to 4.0 and an average of 1.9 (Table 2). The susceptible check cultivars had higher disease severity in all three experiments, although the visual ratings were in the range of moderately resistant to moderately susceptible at $8 \mathrm{WAI}$ in the two 2011 experiments (Tables 1 and 2). One of the resistant check cultivars, Ho 95-988, had erratic results based on disease severity assessed visually, with a 7.2 rating at $12 \mathrm{WAI}$ in the 2012 experiment (Table 3). Averaged across all three experiments, the resistant check cultivars had lower ratings than the susceptible check cultivars (Table 4). The average ratings for the resistant checks were in the resistant ratings interval of 1 to 3 at 8 and 12 WAI, whereas the susceptible check average ratings were in the moderately susceptible ratings interval of 4 to 6 .

Bacterial populations determined by qPCR. The $X$. albilineans population quantified by $\mathrm{qPCR}$ varied among clones and plant

Table 1. Evaluation of leaf scald resistance in 31 sugarcane clones using the visual rating of systemic symptom development and the bacterial population quantified by quantitative polymerase chain reaction at 8 and 12 weeks after inoculation (WAI) on 16 June 2011

\begin{tabular}{|c|c|c|c|c|c|c|c|}
\hline \multirow[b]{2}{*}{ Clone } & \multicolumn{2}{|c|}{ Visual rating ${ }^{a}$} & \multicolumn{5}{|c|}{ Bacterial population $(\mathrm{CFU} / \mathrm{ml})^{\mathrm{b}}$} \\
\hline & 8 & 12 & $8 \mathrm{SS}$ & $8 \mathrm{CS}$ & $12 \mathrm{CS}$ & Stem base & $\overline{\text { Meristem }}$ \\
\hline CP 65-357 & 4.3 & 4.4 & $8.07 \mathrm{E}+07$ & $1.02 \mathrm{E}+07$ & $2.33 \mathrm{E}+07$ & $2.72 \mathrm{E}+06$ & $2.25 \mathrm{E}+07$ \\
\hline CP 70-321 & 2.7 & 2.5 & $7.38 \mathrm{E}+08$ & $7.47 \mathrm{E}+06$ & $6.11 \mathrm{E}+07$ & $1.84 \mathrm{E}+07$ & $2.26 \mathrm{E}+06$ \\
\hline CP 73-351 & 2.4 & 5.1 & $1.34 \mathrm{E}+08$ & $1.66 \mathrm{E}+07$ & $2.29 \mathrm{E}+07$ & $1.73 \mathrm{E}+07$ & $1.22 \mathrm{E}+07$ \\
\hline LCP 82-89 & 3.8 & 2.4 & $9.78 \mathrm{E}+06$ & $2.66 \mathrm{E}+07$ & $1.51 \mathrm{E}+07$ & $2.78 \mathrm{E}+06$ & $7.60 \mathrm{E}+06$ \\
\hline LCP 85-384 & 1.8 & 2.0 & $8.80 \mathrm{E}+05$ & 0.00 & 0.00 & $1.11 \mathrm{E}+06$ & 0.00 \\
\hline НоСР 85-845 & 4.4 & 6.2 & $1.18 \mathrm{E}+09$ & $3.46 \mathrm{E}+07$ & $4.45 \mathrm{E}+06$ & $1.90 \mathrm{E}+06$ & $1.87 \mathrm{E}+06$ \\
\hline CP 89-2143 & 3.4 & 3.6 & 0.00 & $2.81 \mathrm{E}+06$ & 0.00 & $8.26 \mathrm{E}+06$ & 0.00 \\
\hline НоСР 89-846 & 3.8 & 7.6 & $1.16 \mathrm{E}+09$ & $1.35 \mathrm{E}+08$ & $6.95 \mathrm{E}+06$ & $7.47 \mathrm{E}+05$ & $3.50 \mathrm{E}+06$ \\
\hline Но 95-988 & 1.8 & 1.9 & $5.20 \mathrm{E}+08$ & $2.12 \mathrm{E}+07$ & 0.00 & $5.33 \mathrm{E}+06$ & 0.00 \\
\hline НоСР 96-540 & 1.7 & 1.8 & $3.13 \mathrm{E}+04$ & 0.00 & 0.00 & $5.30 \mathrm{E}+05$ & 0.00 \\
\hline L 97-128 & 6.8 & 5.4 & $2.62 \mathrm{E}+04$ & $1.86 \mathrm{E}+04$ & 0.00 & $4.07 \mathrm{E}+06$ & 0.00 \\
\hline L $99-226$ & 3.7 & 4.3 & $5.98 \mathrm{E}+08$ & $1.81 \mathrm{E}+06$ & $2.97 \mathrm{E}+04$ & $2.10 \mathrm{E}+07$ & 0.00 \\
\hline L 99-233 & 3.9 & 3.1 & $1.70 \mathrm{E}+08$ & $3.07 \mathrm{E}+07$ & $1.14 \mathrm{E}+06$ & $4.90 \mathrm{E}+06$ & 0.00 \\
\hline НоСР 00-950 & 3.2 & 2.1 & $2.02 \mathrm{E}+05$ & $6.36 \mathrm{E}+07$ & $1.46 \mathrm{E}+05$ & $3.53 \mathrm{E}+06$ & 0.00 \\
\hline L $01-283$ & 2.2 & 3.2 & $1.14 \mathrm{E}+08$ & $2.71 \mathrm{E}+06$ & 0.00 & $4.59 \mathrm{E}+06$ & 0.00 \\
\hline L 01-299 & 3.2 & 3.2 & $8.90 \mathrm{E}+08$ & $1.60 \mathrm{E}+06$ & $1.31 \mathrm{E}+07$ & $6.31 \mathrm{E}+05$ & $7.24 \mathrm{E}+06$ \\
\hline L 03-371 & 2.4 & 2.6 & $4.23 \mathrm{E}+04$ & 0.00 & 0.00 & $2.35 \mathrm{E}+06$ & 0.00 \\
\hline НоСР 04-838 & 5.4 & 6.1 & $3.70 \mathrm{E}+07$ & $9.85 \mathrm{E}+07$ & $9.27 \mathrm{E}+07$ & $2.47 \mathrm{E}+07$ & $6.14 \mathrm{E}+07$ \\
\hline Ho $05-961$ & 3.5 & 2.7 & 0.00 & $1.24 \mathrm{E}+07$ & $8.48 \mathrm{E}+06$ & $3.25 \mathrm{E}+07$ & $7.25 \mathrm{E}+06$ \\
\hline L $07-57$ & 2.9 & 2.2 & 0.00 & 0.00 & 0.00 & $4.42 \mathrm{E}+06$ & 0.00 \\
\hline НоСР 07-613 & 2.7 & 4.3 & 0.00 & $1.56 \mathrm{E}+04$ & 0.00 & $8.95 \mathrm{E}+06$ & 0.00 \\
\hline Ho 08-706 & 4.4 & 6.0 & $3.03 \mathrm{E}+07$ & $2.87 \mathrm{E}+07$ & $6.53 \mathrm{E}+06$ & $4.43 E+05$ & $6.88 \mathrm{E}+05$ \\
\hline Ho 08-709 & 3.3 & 4.2 & $7.63 \mathrm{E}+07$ & $1.88 \mathrm{E}+05$ & $7.13 \mathrm{E}+04$ & $7.14 \mathrm{E}+06$ & 0.00 \\
\hline Но 08-711 & 3.0 & 1.8 & 0.00 & $2.68 \mathrm{E}+04$ & 0.00 & $4.67 \mathrm{E}+06$ & 0.00 \\
\hline Но 08-717 & 1.7 & 2.9 & $2.37 \mathrm{E}+05$ & 0.00 & 0.00 & $1.54 \mathrm{E}+07$ & 0.00 \\
\hline Но $08-723$ & 2.9 & 3.0 & 0.00 & $1.01 \mathrm{E}+04$ & 0.00 & $2.40 \mathrm{E}+06$ & 0.00 \\
\hline НоСР 08-726 & 1.8 & 3.8 & $2.57 \mathrm{E}+04$ & $2.90 \mathrm{E}+04$ & 0.00 & $2.84 \mathrm{E}+06$ & 0.00 \\
\hline L $08-75$ & 1.5 & 3.4 & $9.73 \mathrm{E}+03$ & $7.23 \mathrm{E}+03$ & 0.00 & $2.06 \mathrm{E}+07$ & 0.00 \\
\hline L $08-88$ & 1.1 & 1.2 & $8.97 \mathrm{E}+04$ & 0.00 & 0.00 & $1.70 \mathrm{E}+06$ & 0.00 \\
\hline L $08-90$ & 2.7 & 2.9 & $9.10 \mathrm{E}+07$ & $1.50 \mathrm{E}+08$ & $1.23 \mathrm{E}+07$ & $1.23 \mathrm{E}+06$ & $1.37 \mathrm{E}+04$ \\
\hline L 08-92 & 3.0 & 2.6 & $4.14 \mathrm{E}+07$ & $1.09 \mathrm{E}+07$ & $8.03 \mathrm{E}+06$ & $3.90 \mathrm{E}+06$ & 0.00 \\
\hline Average & 3.1 & 3.5 & $1.89 \mathrm{E}+08$ & $2.11 \mathrm{E}+07$ & $8.91 \mathrm{E}+06$ & $7.45 \mathrm{E}+06$ & $4.08 \mathrm{E}+06$ \\
\hline $\operatorname{LSD}^{\mathrm{c}}$ & 1.00 & 1.13 & $2.83^{\mathrm{d}}$ & $2.65^{\mathrm{d}}$ & $1.44^{\mathrm{d}}$ & NSD & $2.77^{\mathrm{d}}$ \\
\hline
\end{tabular}


tissues within the three different experiments and two times after inoculation (Tables 1, 2, and 3). The qPCR amplifications showed reaction efficiencies of 90 to $105 \%$ for the 8 WAI samples $\left(R^{2}=0.95\right.$ to 0.99 ). For the $12 \mathrm{WAI}$ samples, the reaction efficiencies were 89 to $99 \%\left(R^{2}=0.95\right.$ to 0.98$)$.

To confirm the best tissue for detecting differences in $X$. albilineans populations between clones with variable levels of resistance, three different tissues were tested in the two experiments conducted in 2011: the apical meristem, the stem base, and leaf tissue. The source of plant tissue affected bacterial population at 12 WAI $(F=64.20, P<0.001$; Shapiro-Wilk: $\mathrm{W}=0.988, P=0.124)$. Clones could not be distinguished by bacterial population differences in the stem base $(F=1.05, P=0.452)$. However, bacterial population was affected by clone for apical meristem $(F=2.36, P=$ $0.011)$ and composite samples $(F=2.38, P=0.011)$. The apical meristem sample data did not meet the requirement of normality for the analysis (Shapiro-Wilk: $\mathrm{W}=0.90, P<0.001$ ), in part due to a high number of negative samples. At $8 \mathrm{WAI}$, bacterial population was not affected by leaf sampling method in the three experiments $(F=0.26, P=0.611)$. Sampling time was considered as a final factor in the overall analysis with composite samples. Comparing 8 and $12 \mathrm{WAI}$ sampling times in the three experiments, bacterial population was affected by clone $(F=3.80, P<0.001)$, experiment $(F=22.18, P<0.001)$, and time after inoculation $(F=20.10, P<$ $0.001)$.
$X$. albilineans populations quantified by qPCR at $12 \mathrm{WAI}$ in three different plant tissues in the two 2011 experiments had similar overall population averages but variable results among clones and plant tissues (Tables 1 and 2). The bacterial population was high in the stem base of all clones evaluated in the first experiment of 2011, preventing discernment among them for degree of resistance (Table 1). For the second experiment of 2011, five clones tested negative for $X$. albilineans, while the others exhibited variation in the concentration of bacteria; however, the differences in bacterial populations did not distinguish the known resistant and susceptible cultivars (Table 2). For example, in the second experiment of 2011, the resistant check LCP 85-384 had a bacterial population of $3.5 \times 10^{6}$ $\mathrm{CFU} / \mathrm{ml}$ and the susceptible check HoCP $89-846$ had a population of $2.7 \times 10^{6} \mathrm{CFU} / \mathrm{ml}$ in the stem base (Table 2). The population of bacteria in the apical meristem varied among clones and between experiments, with $63 \%$ testing negative for $X$. albilineans in the first experiment of 2011 (Table 1) and $81 \%$ testing negative in the second experiment of 2011 (Table 2).

The apical meristem results showed more agreement with the leaf tissue results at $12 \mathrm{WAI}(\rho=0.87, P<0.001$ for the first experiment of 2011 and $\rho=0.75, P<0.001$ in the second 2011 experiment) than the stem base ( $\rho=0.05, P=0.771$ in the first experiment of 2011 and $\rho=0.16, P=0.403$ in the second experiment of 2011). All of the positive clones in the apical meristem were positive in the leaf tissue; however, some positive samples by qPCR from leaf tissue were

Table 2. Evaluation of leaf scald resistance in 31 sugarcane clones using the visual rating of systemic symptom development and the bacterial population quantified by quantitative polymerase chain reaction at 8 and 12 weeks after inoculation (WAI) on 1 July 2011

\begin{tabular}{|c|c|c|c|c|c|c|c|}
\hline \multirow[b]{2}{*}{ Clone } & \multicolumn{2}{|c|}{ Visual rating ${ }^{\mathbf{a}}$} & \multicolumn{5}{|c|}{ Bacterial population $(\mathrm{CFU} / \mathrm{ml})^{\mathrm{b}}$} \\
\hline & 8 & 12 & $8 \mathrm{SS}$ & $8 \mathrm{CS}$ & $12 \mathrm{CS}$ & Stem base & Meristem \\
\hline CP 65-357 & 2.4 & 2.3 & $7.09 \mathrm{E}+03$ & $3.13 \mathrm{E}+08$ & $7.17 \mathrm{E}+05$ & 7.19E+06 & 0.00 \\
\hline CP 70-321 & 1.3 & 3.0 & 0.00 & 0.00 & 0.00 & $1.47 \mathrm{E}+07$ & 0.00 \\
\hline CP 73-351 & 1.7 & 1.6 & 0.00 & 0.00 & $3.14 \mathrm{E}+07$ & $2.07 \mathrm{E}+07$ & $3.06 \mathrm{E}+07$ \\
\hline LCP $82-89$ & 3.0 & 3.2 & $2.36 \mathrm{E}+08$ & 0.00 & $3.90 \mathrm{E}+06$ & $3.14 \mathrm{E}+06$ & $4.11 \mathrm{E}+05$ \\
\hline LCP 85-384 & 1.2 & 1.4 & 0.00 & 0.00 & $6.87 \mathrm{E}+03$ & $3.50 \mathrm{E}+06$ & 0.00 \\
\hline НоСР 85-845 & 4.0 & 4.8 & $2.65 \mathrm{E}+04$ & $3.01 \mathrm{E}+08$ & $2.53 \mathrm{E}+07$ & $3.48 \mathrm{E}+07$ & $5.83 \mathrm{E}+06$ \\
\hline CP 89-2143 & 1.6 & 2.3 & $9.73 \mathrm{E}+04$ & 0.00 & 0.00 & $2.44 \mathrm{E}+07$ & 0.00 \\
\hline НоСР 89-846 & 3.0 & 5.9 & 0.00 & $1.11 \mathrm{E}+09$ & $4.69 \mathrm{E}+07$ & $2.73 \mathrm{E}+06$ & $4.30 \mathrm{E}+07$ \\
\hline Но 95-988 & 1.2 & 1.4 & $7.47 \mathrm{E}+03$ & 0.00 & 0.00 & $4.67 \mathrm{E}+07$ & 0.00 \\
\hline НоСР 96-540 & 1.4 & 2.0 & 0.00 & 0.00 & 0.00 & $2.66 \mathrm{E}+05$ & 0.00 \\
\hline L 97-128 & 1.2 & 2.7 & $1.49 \mathrm{E}+04$ & 0.00 & $3.07 \mathrm{E}+04$ & 0.00 & 0.00 \\
\hline L 99-226 & 2.7 & 3.5 & $1.00 \mathrm{E}+09$ & $1.03 \mathrm{E}+05$ & 0.00 & $2.91 \mathrm{E}+06$ & 0.00 \\
\hline L 99-233 & 2.4 & 2.3 & $2.70 \mathrm{E}+08$ & 0.00 & 0.00 & 0.00 & 0.00 \\
\hline НоСР 00-950 & 3.0 & 4.8 & $1.16 \mathrm{E}+07$ & 0.00 & 0.00 & $1.38 \mathrm{E}+06$ & 0.00 \\
\hline L $01-283$ & 2.5 & 3.2 & 0.00 & $4.60 \mathrm{E}+03$ & 0.00 & $1.80 \mathrm{E}+06$ & 0.00 \\
\hline L 01-299 & 2.5 & 2.5 & $1.44 \mathrm{E}+08$ & $7.10 \mathrm{E}+03$ & $4.90 \mathrm{E}+03$ & $1.85 \mathrm{E}+07$ & 0.00 \\
\hline L 03-371 & 1.3 & 2.1 & 0.00 & $2.77 \mathrm{E}+08$ & 0.00 & $7.00 \mathrm{E}+06$ & 0.00 \\
\hline НоСР 04-838 & 2.0 & 3.4 & 0.00 & $9.73 \mathrm{E}+04$ & 0.00 & $4.10 \mathrm{E}+06$ & 0.00 \\
\hline Но 05-961 & 1.0 & 5.2 & 0.00 & 0.00 & 0.00 & $3.75 \mathrm{E}+07$ & 0.00 \\
\hline L $07-57$ & 1.2 & 2.8 & $\mathrm{ND}$ & $2.60 \mathrm{E}+08$ & 0.00 & 0.00 & 0.00 \\
\hline НоСР 07-613 & 1.7 & 7.8 & 0.00 & $1.45 \mathrm{E}+04$ & 0.00 & $9.93 \mathrm{E}+05$ & 0.00 \\
\hline Но 08-706 & 1.7 & 1.8 & 0.00 & $1.49 \mathrm{E}+04$ & 0.00 & $1.04 \mathrm{E}+06$ & 0.00 \\
\hline Но 08-709 & 2.1 & 2.8 & 0.00 & 0.00 & $6.49 \mathrm{E}+06$ & $1.48 \mathrm{E}+07$ & $8.77 \mathrm{E}+06$ \\
\hline Ho 08-711 & 1.4 & 1.9 & $1.08 \mathrm{E}+04$ & $2.70 \mathrm{E}+08$ & 0.00 & $6.01 \mathrm{E}+06$ & 0.00 \\
\hline Ho $08-717$ & 1.8 & 3.0 & $4.48 \mathrm{E}+03$ & 0.00 & 0.00 & 0.00 & 0.00 \\
\hline Но 08-723 & 1.3 & 3.2 & $7.10 \mathrm{E}+03$ & $2.36 \mathrm{E}+08$ & $2.91 \mathrm{E}+03$ & 0.00 & 0.00 \\
\hline НоСР 08-726 & 2.2 & 3.1 & 0.00 & 0.00 & 0.00 & $3.16 \mathrm{E}+04$ & 0.00 \\
\hline L $08-75$ & 1.4 & 1.5 & $1.03 \mathrm{E}+05$ & $1.16 \mathrm{E}+07$ & 0.00 & $5.94 \mathrm{E}+06$ & 0.00 \\
\hline L $08-88$ & 1.0 & 1.2 & 0.00 & 0.00 & 0.00 & $4.40 \mathrm{E}+07$ & 0.00 \\
\hline L 08-90 & 1.6 & 3.4 & 0.00 & 0.00 & 0.00 & $3.16 \mathrm{E}+03$ & 0.00 \\
\hline L $08-92$ & 2.0 & 3.9 & $2.77 \mathrm{E}+08$ & $1.38 \mathrm{E}+05$ & $1.06 \mathrm{E}+06$ & $1.07 \mathrm{E}+06$ & 0.00 \\
\hline Average & 1.9 & 3.0 & $6.48 \mathrm{E}+07$ & $8.95 \mathrm{E}+07$ & $3.74 \mathrm{E}+06$ & $9.85 \mathrm{E}+06$ & $2.86 \mathrm{E}+06$ \\
\hline $\mathrm{LSD}^{\mathrm{c}}$ & 0.78 & 1.10 & $2.82^{\mathrm{d}}$ & $2.96^{\mathrm{d}}$ & $1.32^{\mathrm{d}}$ & NSD & $2.48^{\mathrm{d}}$ \\
\hline
\end{tabular}


negative for the apical meristem evaluation. In the first experiment of 2011, the clones L 99-233, L 99-226, HoCP 00-950, Ho 08-709, and L 08-92 were positive for $X$. albilineans in leaf tissue collected 12 WAI but negative in the apical meristem (Table 1). In the second experiment of 2011, the clones CP 65-357, LCP 85-384, L 97-128,

Table 3. Evaluation of leaf scald resistance in 31 sugarcane clones using the visual rating of systemic symptom development and the bacterial population quantified by quantitative polymerase chain reaction at 8 and 12 weeks after inoculation (WAI) on 28 May 2012

\begin{tabular}{|c|c|c|c|c|c|}
\hline \multirow[b]{2}{*}{ Clone $^{c}$} & \multicolumn{2}{|c|}{ Visual rating ${ }^{\mathbf{a}}$} & \multicolumn{3}{|c|}{ Bacterial population $(\mathrm{CFU} / \mathrm{ml})^{\mathrm{b}}$} \\
\hline & 8 & 12 & $8 \mathrm{SS}$ & $8 \mathrm{CS}$ & $12 \mathrm{CS}$ \\
\hline CP 65-357 & 4.3 & 5.0 & $3.75 \mathrm{E}+07$ & $1.09 \mathrm{E}+08$ & $1.40 \mathrm{E}+08$ \\
\hline CP 70-321 & 2.8 & 1.7 & $1.06 \mathrm{E}+08$ & $4.30 \mathrm{E}+06$ & $1.76 \mathrm{E}+08$ \\
\hline CP 73-351 & 4.9 & 4.8 & $5.02 \mathrm{E}+08$ & $3.92 \mathrm{E}+08$ & $3.67 \mathrm{E}+06$ \\
\hline LCP 82-89 & 2.8 & 4.0 & $4.81 \mathrm{E}+07$ & $9.13 \mathrm{E}+07$ & $3.77 \mathrm{E}+06$ \\
\hline LCP 85-384 & 1.0 & 1.0 & $9.50 \mathrm{E}+02$ & 0.00 & 0.00 \\
\hline НоСР 85-845 & 5.6 & 6.4 & $4.21 \mathrm{E}+08$ & $8.14 \mathrm{E}+07$ & $1.05 \mathrm{E}+08$ \\
\hline CP 89-2143 & 5.3 & 5.4 & $7.86 \mathrm{E}+05$ & $1.05 \mathrm{E}+08$ & $3.01 \mathrm{E}+07$ \\
\hline НоСР 89-846 & 7.8 & 6.9 & $1.93 \mathrm{E}+09$ & $1.03 \mathrm{E}+09$ & $8.27 \mathrm{E}+06$ \\
\hline Ho 95-988 & 3.1 & 7.2 & $1.64 \mathrm{E}+07$ & $2.01 \mathrm{E}+08$ & $1.10 \mathrm{E}+06$ \\
\hline НоСР 96-540 & 2.0 & 1.0 & $1.09 \mathrm{E}+07$ & $1.80 \mathrm{E}+07$ & 0.00 \\
\hline L 97-128 & 1.9 & 5.3 & $1.70 \mathrm{E}+03$ & $1.00 \mathrm{E}+06$ & $6.90 \mathrm{E}+02$ \\
\hline L 99-226 & 3.0 & 5.3 & $7.13 \mathrm{E}+08$ & $2.70 \mathrm{E}+08$ & $5.33 \mathrm{E}+06$ \\
\hline L 99-233 & 5.3 & 5.6 & $1.46 \mathrm{E}+08$ & $1.60 \mathrm{E}+07$ & $5.91 \mathrm{E}+07$ \\
\hline НоСР 00-950 & 5.5 & 1.5 & $3.95 \mathrm{E}+07$ & $6.33 \mathrm{E}+08$ & $1.14 \mathrm{E}+08$ \\
\hline L $01-283$ & 2.9 & 2.4 & $7.00 \mathrm{E}+02$ & 0.00 & 0.00 \\
\hline L 01-299 & 3.5 & 4.9 & $1.86 \mathrm{E}+08$ & $2.79 \mathrm{E}+08$ & $6.13 \mathrm{E}+02$ \\
\hline L 03-371 & 4.2 & 2.8 & $5.16 \mathrm{E}+07$ & $6.88 \mathrm{E}+07$ & $6.80 \mathrm{E}+02$ \\
\hline НоСР 04-838 & 5.2 & 6.6 & $3.29 \mathrm{E}+08$ & $3.59 \mathrm{E}+08$ & $1.85 \mathrm{E}+08$ \\
\hline Но 05-961 & 4.0 & 1.0 & $4.76 \mathrm{E}+05$ & $4.82 \mathrm{E}+05$ & $4.93 \mathrm{E}+06$ \\
\hline L $07-57$ & 1.9 & 1.9 & 0.00 & 0.00 & 0.00 \\
\hline Но 08-706 & 3.3 & 3.8 & $1.87 \mathrm{E}+05$ & $1.07 \mathrm{E}+08$ & $1.08 \mathrm{E}+06$ \\
\hline Но 08-709 & 3.1 & 3.6 & $1.93 \mathrm{E}+08$ & $6.86 \mathrm{E}+07$ & $7.03 \mathrm{E}+06$ \\
\hline Но 08-711 & 3.0 & 2.5 & $1.64 \mathrm{E}+03$ & $6.87 \mathrm{E}+07$ & 0.00 \\
\hline Ho 08-717 & 3.0 & 3.2 & $3.13 \mathrm{E}+02$ & $1.84 \mathrm{E}+05$ & 0.00 \\
\hline Но $08-723$ & 3.2 & 6.8 & $1.95 \mathrm{E}+07$ & $7.69 \mathrm{E}+07$ & $1.52 \mathrm{E}+03$ \\
\hline НоСР 08-726 & 1.8 & 2.0 & 0.00 & $1.04 \mathrm{E}+08$ & $4.44 \mathrm{E}+04$ \\
\hline L $08-75$ & 1.8 & 5.2 & $1.81 \mathrm{E}+05$ & $2.79 E+04$ & $5.37 \mathrm{E}+03$ \\
\hline L $08-88$ & 1.8 & 2.6 & $4.41 \mathrm{E}+03$ & $2.06 \mathrm{E}+07$ & 0.00 \\
\hline L $08-90$ & 4.6 & 1.2 & $1.11 \mathrm{E}+09$ & $7.84 \mathrm{E}+06$ & $1.38 \mathrm{E}+07$ \\
\hline L 08-92 & 3.0 & 1.2 & $1.59 \mathrm{E}+08$ & $3.24 \mathrm{E}+08$ & $1.21 \mathrm{E}+05$ \\
\hline Average & 3.5 & 3.8 & $2.01 \mathrm{E}+08$ & $1.48 \mathrm{E}+08$ & $2.86 \mathrm{E}+07$ \\
\hline $\operatorname{LSD}^{\mathrm{d}}$ & 1.12 & 1.31 & $2.67^{\mathrm{e}}$ & $1.26^{\mathrm{e}}$ & $1.38^{\mathrm{e}}$ \\
\hline
\end{tabular}

a Visual ratings at 8 and 12 WAI were assigned on a 1-to- 9 scale, where $1=$ highly resistant and $9=$ highly susceptible for 13 to 18 stalks per clone.

b Bacterial populations at 8 and 12 WAI. Data based on three samples per clone. $\mathrm{SS}=$ single (one) leaf per sample and $\mathrm{CS}=$ composite sample with three leaves per sample.

c Clone Ho 08-709 could not be evaluated in the 2012 inoculation.

${ }^{d}$ Least significant difference (LSD) was calculated with a $95 \%$ confidence level.

e Bacterial populations were transformed $\left(\log _{10}\right)$ prior to LSD calculation because the data did not meet normality requirements.
L 01-299, Ho 08-723, and L 08-92 were positive in leaf tissue but negative in the apical meristem (Table 2).

The average $X$. albilineans populations in the three experiments for the susceptible checks were high. At $8 \mathrm{WAI}$, the averages of the populations were $1.03 \times 10^{9} \mathrm{CFU} / \mathrm{ml}$ in single-leaf samples and $7.58 \times 10^{8} \mathrm{CFU} / \mathrm{ml}$ in composite samples of HoCP 89-846, and $5.34 \times 10^{8}$ in single-leaf samples and $1.39 \times 10^{8} \mathrm{CFU} / \mathrm{ml}$ in composite samples of HoCP 85-845 (Table 4). The average concentrations were lower at $12 \mathrm{WAI}$ with $2.07 \times 10^{7} \mathrm{CFU} / \mathrm{ml}$ for $\mathrm{HoCP}$ $89-846$ and $4.49 \times 10^{7} \mathrm{CFU} / \mathrm{ml}$ for HoCP $85-845$. The averages for the resistant check cultivars were lower than the susceptible checks at $8 \mathrm{WAI}$ with $2.94 \times 10^{5} \mathrm{CFU} / \mathrm{ml}$ in single-leaf samples and none detected in composite samples of LCP 85-384, $1.79 \times 10^{8}$ $\mathrm{CFU} / \mathrm{ml}$ in single-leaf samples and $7.41 \times 10^{7} \mathrm{CFU} / \mathrm{ml}$ in composite samples of Ho 95-988, and $3.64 \times 10^{6} \mathrm{CFU} / \mathrm{ml}$ in single-leaf samples and $6.0 \times 10^{6} \mathrm{CFU} / \mathrm{ml}$ in composite samples of HoCP 96-540 (Table 4).

The three resistant check cultivars gave variable results in different experiments for bacterial populations at $8 \mathrm{WAI}$ (Tables 1, 2, and 3). Bacteria were not detected in all three experiments for LCP 85-384 for the composite sample but populations of $8.8 \times 10^{5}$ and $9.5 \times 10^{2} \mathrm{CFU} / \mathrm{ml}$ were detected in the first 2011 experiment and the 2012 experiment, respectively, for single-leaf samples. For Ho 95-988, populations of $5.2 \times 10^{8}, 7.47 \times 10^{7}$, and $1.64 \times$ $10^{7} \mathrm{CFU} / \mathrm{ml}$ were detected in single-leaf samples and $2.12 \times 10^{7}$, 0 , and $2.01 \times 10^{8} \mathrm{CFU} / \mathrm{ml}$ were detected in composite samples for the first and second 2011 experiments and 2012 experiment, respectively. For HoCP 96-540, populations of $3.13 \times 10^{4}$, 0 , and $1.09 \times 10^{7} \mathrm{CFU} / \mathrm{ml}$ were detected in single-leaf samples and populations of 0,0 , and $1.80 \times 10^{7} \mathrm{CFU} / \mathrm{ml}$ were detected in composite samples for the three experiments, respectively. At $12 \mathrm{WAI}$, no bacteria were detected in composite samples for any of the resistant checks, except for $6.87 \times 10^{3} \mathrm{CFU} / \mathrm{ml}$ for LCP $85-384$ in the second 2011 experiment (Table 2) and $1.1 \times 10^{6}$ for Ho 95-988 in the 2012 experiment (Table 3). At $12 \mathrm{WAI}$ in the first experiment of $2011,48 \%$ of the clones were negative based on qPCR, and $65 \%$ of the clones were negative in the second experiment of 2011. However, only $23 \%$ of the clones were negative in the 2012 experiment. These data contrast with the lower negative results obtained in the bacterial populations counted at 8 WAI. In the first experiment of 2011 , only $19 \%$ of the clones were negative based on both the single- and composite samples. For the second experiment of $2011,48 \%$ of the clones were negative based on the single-leaf sample and $52 \%$ were negative based on the composite sample results. For the 2012 experiment, only 7 and $10 \%$ of the samples were negative using the single-leaf and the composite sample methods, respectively.

$X$. albilineans populations quantified by $\mathrm{qPCR}$ in single-leaf or composite samples were tested for correlation across the three experiments and between bacterial populations and visual severity ratings for each experiment. The Spearman's correlation coefficients between the sampling methods (single-leaf and composite sample) were low to moderate for the three different experiments performed in this study. When the correlations between the single-leaf and composite sampling methods were measured at $8 \mathrm{WAI}$, the first experiment of

Table 4. Averages from three inoculations of check cultivars susceptible and resistant to leaf scald for symptom severity ratings and bacterial populations in leaf samples quantified by quantitative polymerase chain reaction

\begin{tabular}{|c|c|c|c|c|c|c|}
\hline \multirow[b]{2}{*}{ Clone } & \multirow[b]{2}{*}{ Disease susceptibility } & \multicolumn{2}{|c|}{ Visual ratinga $^{a}$} & \multicolumn{3}{|c|}{ Bacterial population $(\mathrm{CFU} / \mathrm{ml})^{\mathrm{b}}$} \\
\hline & & 8 & 12 & $8 \mathrm{SS}$ & $8 \mathrm{CS}$ & $12 \mathrm{CS}$ \\
\hline НоСР $85-845$ & Susceptible & 4.7 & 5.8 & $5.34 \mathrm{E}+08$ & $1.39 \mathrm{E}+08$ & $4.49 \mathrm{E}+07$ \\
\hline НоСР 89-846 & Susceptible & 4.9 & 6.8 & $1.03 \mathrm{E}+09$ & $7.58 \mathrm{E}+08$ & $2.07 \mathrm{E}+07$ \\
\hline LCP 85-384 & Resistant & 1.3 & 1.5 & $2.94 \mathrm{E}+05$ & 0.00 & $2.29 \mathrm{E}+03$ \\
\hline Но 95-988 & Resistant & 2.0 & 3.5 & $1.79 \mathrm{E}+08$ & $7.41 \mathrm{E}+07$ & $3.67 \mathrm{E}+05$ \\
\hline НоСР 96-540 & Resistant & 1.7 & 1.6 & $3.64 \mathrm{E}+06$ & $6.00 \mathrm{E}+06$ & 0.00 \\
\hline
\end{tabular}

a Visual ratings 8 and 12 weeks after inoculation (WAI) were assigned on a 1-to-9 scale, where $1=$ highly resistant and $9=$ highly susceptible for 13 to 18 stalks per clone.

b Bacterial populations at 8 and 12 WAI. SS = single (one) leaf per sample and CS = composite sample with three leaves per sample. 
$2011(\rho=0.55, P=0.001)$ and the experiment performed in 2012 ( $\rho=0.59, P=0.001)$ showed a moderate correlation between the bacterial population obtained using the single-leaf and composite samples. However, the Spearman's correlation coefficient obtained in the second experiment of $2011(\rho=0.14, P=0.449)$ was low and statistically nonsignificant.

Comparisons between disease severity ratings and bacterial populations. The evaluation of the check cultivars showed some differences between the visual severity ratings and the bacterial populations in leaf samples determined by qPCR at 8 WAI. The susceptible check cultivars all had moderately resistant to moderately susceptible visual severity ratings, with averages of 4.7 for HoCP

Table 5. Correlation between symptom severity ratings and Xanthomonas albilineans populations determined by quantitative polymerase chain reaction in infected tissues of 31 sugarcane clones at 8 and 12 weeks after inoculation (WAI)

\begin{tabular}{lrlcr}
\hline Experiment & WAI & Tissue evaluated $^{\mathbf{a}}$ & $\boldsymbol{\rho}^{\mathbf{b}}$ & \multicolumn{1}{c}{$\boldsymbol{P}$} \\
\hline First experiment 2011 & 8 & Leaf (single) & 0.27 & 0.15 \\
& 8 & Leaf (composite) & 0.58 & $<0.01$ \\
& 12 & Leaf (composite) & 0.32 & 0.08 \\
& 12 & Apical meristem & 0.39 & 0.03 \\
Second experiment 2011 & 12 & Stem base & 0.28 & 0.12 \\
& 8 & Leaf (single) & 0.37 & 0.05 \\
& 8 & Leaf (composite) & 0.48 & 0.01 \\
& 12 & Leaf (composite) & 0.13 & 0.47 \\
Experiment 2012 & 12 & Apical meristem & 0.20 & 0.28 \\
& 12 & Stem base & 0.06 & 0.76 \\
& 8 & Leaf (single) & 0.56 & $<0.01$ \\
& 8 & Leaf (composite) & 0.62 & $<0.01$ \\
& 12 & Leaf (composite) & 0.33 & 0.07 \\
\hline
\end{tabular}

a Single-leaf sample was one leaf per plant with three leaves per clone. Composite was a sample of three leaves each from three different plants of the same clone.

b Spearman's rank correlation coefficient $(\rho)$.

Table 6. Pearson correlation of the symptom severity rating data for 31 sugarcane clones at 8 and 12 weeks after inoculation (WAI) among the field experiments in 2011 and 2012

\begin{tabular}{lrlll}
\hline & & \multicolumn{2}{c}{$\boldsymbol{r}(\boldsymbol{P})^{\mathbf{a}}$} & \\
\cline { 3 - 4 } & & First experiment & $\begin{array}{c}\text { Second } \\
\text { experiment 2011 }\end{array}$ & $\begin{array}{c}\text { Experiment } \\
\mathbf{2 0 1 2}\end{array}$ \\
\hline First 2011 & 8 & 1 & $\ldots$ & $\ldots$ \\
Second & 12 & 1 & $\ldots$ & $\ldots$ \\
2011 & 8 & $0.33(0.07)$ & 1 & $\ldots$ \\
2012 & 12 & $0.35(0.05)$ & 1 & $\ldots$ \\
& 8 & $0.38(0.04)$ & $0.53(<0.01)$ & 1 \\
& 12 & $0.60(<0.01)$ & $0.02(0.93)$ & 1 \\
\hline
\end{tabular}

${ }^{a}$ Pearson product moment correlation coefficient $(r)$.
85-845 and 4.9 for HoCP 89-846; however, high bacterial populations were detected by qPCR: $5.34 \times 10^{8} \mathrm{CFU} / \mathrm{ml}$ for HoCP 85 845 and $1.03 \times 10^{9} \mathrm{CFU} / \mathrm{ml}$ for HoCP $89-846$ in the single-leaf samples, and $1.39 \times 10^{8} \mathrm{CFU} / \mathrm{ml}$ for HoCP $85-845$ and $7.58 \times$ $10^{8} \mathrm{CFU} / \mathrm{ml}$ for HoCP $89-846$ in composite samples (Table 4). The resistant check Ho 95-988 had visual severity ratings of 1.8 and 3.1 compared with 4.4 and 5.6 for susceptible HoCP $85-845$ for the first 2011 experiment and 2012 experiment, respectively, but similar bacterial populations of $5.20 \times 10^{8} \mathrm{CFU} / \mathrm{ml}$ for $\mathrm{Ho}$ 95-988 and $1.18 \times 10^{9} \mathrm{CFU} / \mathrm{ml}$ for HoCP $85-845$ in the first experiment of 2011 and $1.64 \times 10^{7} \mathrm{CFU} / \mathrm{ml}$ for Ho $95-988$ and $4.21 \times$ $10^{8} \mathrm{CFU} / \mathrm{ml}$ for HoCP $85-845$ in 2012 for single-leaf samples. Populations were $2.12 \times 10^{7} \mathrm{CFU} / \mathrm{ml}$ for Ho $95-988$ and $3.46 \times$ $10^{7} \mathrm{CFU} / \mathrm{ml}$ for HoCP $85-845$ in 2011 and $2.01 \times 10^{8} \mathrm{CFU} / \mathrm{ml}$ for Ho $95-988$ and $8.14 \times 10^{7} \mathrm{CFU} / \mathrm{ml}$ for HoCP $85-845$ in 2012 for composite samples. An average bacterial population of $6.0 \times 10^{7} \mathrm{CFU} / \mathrm{ml}$ was detected in resistant check HoCP 96-540 at $8 \mathrm{WAI}\left(1.80 \times 10^{7} \mathrm{CFU} / \mathrm{ml}\right)$, and that bacterial population was paired with a visual rating of 2.0. However, bacteria were not detected in HoCP 96-540 at 12 WAI.

Correlation between visual disease severity ratings and bacterial populations. The Spearman's rank correlation coefficients between visual severity ratings and bacterial populations for single-leaf samples were lower than for composite samples (Table 5). The composite sample correlations at $8 \mathrm{WAI}$ for all three field experiments $(\rho=0.58$, 0.48 , and 0.62 ) were higher than the correlations obtained with any other sampling method or time after inoculation. At $12 \mathrm{WAI}$, the correlations between visual severity ratings and $X$. albilineans populations in systemically infected leaves were not significant (Table 5). A comparison of severity ratings and bacterial populations in other plant tissues at $12 \mathrm{WAI}$ found low correlation for stem base and apical meristem samples for the 2011 experiments. Correlation results for the stem base were not significant but a significant correlation was found for the apical meristem in the first experiment of 2011 (Table 5).

Correlation among experiments for each resistance evaluation method. The data for resistance evaluation using visual ratings at 8 WAI showed low to medium positive correlations among the different experiments; however, only two of the coefficients were significant (Table 6). The bacterial populations determined by qPCR at 8 WAI were compared among different experiments and sampling methods. Data from single-leaf samples were not correlated between the two different experiments performed in 2011 in the field (Table 7). In contrast, the composite sample data showed medium to high correlation among the three field experiment comparisons, with positive correlation coefficients of 0.55 to 0.77 (Table 7). When the single-leaf sampling data were compared with the composite sampling data of the same year, the correlation coefficients were low and not significant for the 2011 experiments; however, the comparison between the single- and composite leaf sampling of 2012 was high and significant (Table 7).

The Pearson correlation analysis results for visual symptom rating data at 12 WAI were variable among the different experiments

Table 7. Pearson correlation of the Xanthomonas albilineans population data at 8 weeks after inoculation among three field inoculations and two leaf sampling methods in 2011 and 2012

\begin{tabular}{|c|c|c|c|c|c|c|c|}
\hline \multirow[b]{3}{*}{ Inoculation } & \multirow[b]{3}{*}{ Type $^{\mathbf{a}}$} & \multicolumn{6}{|c|}{ Pearson correlation per inoculation $(P)$} \\
\hline & & \multicolumn{2}{|c|}{ First 2011} & \multicolumn{2}{|c|}{ Second 2011} & \multicolumn{2}{|c|}{2012} \\
\hline & & SS & CS & SS & CS & SS & CS \\
\hline \multirow[t]{2}{*}{ First 2011} & SS & 1 & $\ldots$ & $\cdots$ & $\cdots$ & $\cdots$ & $\ldots$ \\
\hline & $\mathrm{CS}$ & $0.29(0.11)$ & 1 & $\ldots$ & $\ldots$ & $\ldots$ & $\ldots$ \\
\hline \multirow[t]{2}{*}{ Second 2011} & SS & $0.20(0.28)$ & $-0.10(0.60)$ & 1 & $\ldots$ & $\ldots$ & $\ldots$ \\
\hline & $\mathrm{CS}$ & $0.49(0.01)$ & $0.55(<0.01)$ & $-0.13(0.49)$ & 1 & $\ldots$ & $\ldots$ \\
\hline \multirow[t]{2}{*}{2012} & SS & $0.45(0.01)$ & $0.56(<0.01)$ & $0.11(0.58)$ & $0.58(<0.01)$ & 1 & $\ldots$ \\
\hline & CS & $0.58(<0.01)$ & $0.77(<0.01)$ & $0.19(0.33)$ & $0.65(<0.01)$ & $0.67(<0.01)$ & 1 \\
\hline
\end{tabular}

a Sample type. Single $(\mathrm{SS})=$ one leaf per plant with three samples taken for each clone. Composite $(\mathrm{CS})=$ three leaves collected from each of three different plants per sample. 
performed in the field between 2011 and 2012 (Table 6). For the bacterial population data based on composite samples, the first experiment of 2011 and the 2012 experiment were correlated (Table 8). For the visual rating method, the correlation was positive and medium $(r=0.60, P=0.001)$ (Table 6$)$, whereas it was higher $(r=0.75, P<0.001)$ for the bacterial population (Table 8). However, the results obtained showed fewer correlations among data obtained in different seasons. The bacterial populations present in the stem base and apical meristem were not correlated between the first and second experiments of 2011. For the stem base, the Pearson's correlation coefficient was $0.19(P=0.297)$. For the apical meristem, the correlation coefficient was $0.05(P=0.775)$.

\section{Discussion}

A correlation demonstrated between $X$. albilineans populations in the shoot apex and disease severity (Rott et al. 1997) suggested that a method to accurately quantify bacteria could provide an improved method for resistance screening, which traditionally has been done by rating erratic symptom expression following inoculation (Rott and Davis 2000). A qPCR technique for the indirect quantification of $X$. albilineans by DNA concentration was developed that could clearly differentiate a limited number of clones with either high leaf scald resistance or susceptibility (Garces et al. 2014). The results from this study demonstrated that quantification of $X$. albilineans by qPCR can distinguish differences among a population of clones with variable levels of resistance to leaf scald. The finding of the previous study (Garces et al. 2014) that young, systemically infected leaves were the best tissue for detecting differences between clones was confirmed. The Spearman's correlation coefficients between visual disease severity ratings and bacterial populations and correlation of bacterial populations among experiments suggested that a composite leaf sample will provide more consistent quantification of bacterial populations by qPCR. Leaf sampling is easy and relatively noninvasive, and DNA extraction does not require special methods or kits.

The time after inoculation for DNA extraction was found to affect the results. Even resistant genotypes become infected following inoculation with a high concentration of bacteria, but resistance expression resulted in reduced $X$. albilineans colonization during systemic infection (Garces et al. 2014; Rott et al. 1997). Data taken 8 and 12 WAI showed variation among clones that was generally associated with resistance and susceptibility in cultivars with known reactions against the disease. The visual ratings for the highly susceptible check cultivars ranged from moderately resistant to moderately susceptible at $8 \mathrm{WAI}$, whereas high $X$. albilineans populations were detected by qPCR. The resistant checks received resistant visual ratings but moderate to high bacterial populations were detected in some experiments for two of three resistant checks. At $12 \mathrm{WAI}$, the visual ratings for the susceptible checks were higher but the bacterial populations decreased slightly. The ratings for the resistant checks were still resistant, and the bacterial populations were generally lower in relation to the susceptible checks. However, the correlation among the data collected using the same evaluation method in different field experiments was not significant for both visual ratings and bacterial populations at 12 WAI. The data collected at $8 \mathrm{WAI}$ showed the highest correlation in the three different field experiments for both visual ratings and $X$. albilineans populations. In addition, Spearman's rank tests comparing the data for

Table 8. Pearson correlation of Xanthomonas albilineans population data at 12 weeks after inoculation among three field experiments in 2011 and $2012^{\mathrm{a}}$

\begin{tabular}{|c|c|c|c|c|c|c|}
\hline \multirow[b]{2}{*}{ Experiment } & \multicolumn{2}{|c|}{$\begin{array}{l}\text { First experiment } \\
\qquad 2011\end{array}$} & \multicolumn{2}{|c|}{$\begin{array}{c}\text { Second experiment } \\
2011\end{array}$} & \multicolumn{2}{|c|}{$\begin{array}{l}\text { Experiment } \\
2012\end{array}$} \\
\hline & $r$ & $P$ & $r$ & $P$ & $r$ & $P$ \\
\hline First 2011 & 1 & $\ldots$ & $\ldots$ & $\ldots$ & $\ldots$ & $\cdots$ \\
\hline Second 2011 & 0.03 & 0.86 & 1 & $\ldots$ & $\ldots$ & $\ldots$ \\
\hline 2012 & 0.75 & $<0.01$ & $<0.01$ & 0.99 & 1 & $\ldots$ \\
\hline
\end{tabular}

a Pearson product moment correlation coefficient $=r$. visual ratings and bacterial populations in leaf tissue showed the highest correlation at 8 WAI.

Correlation analyses of the data collected in different experiments measured the reliability of each evaluation method for accurately determining the susceptibility of a clone to leaf scald under variable environmental conditions in different seasons. Quantification of the bacterial population was more highly correlated and, therefore, more stable and repeatable than resistance evaluation based on rating symptom severity, the traditional method. High bacterial populations were always detected in systemically infected leaves of known susceptible cultivars. However, a severe inoculation with $X$. albilineans resulted in successful systemic colonization of known resistant cultivars in some cases. Apparently, inoculation can sometimes overcome resistance to systemic infection in some resistant genotypes. The severe wounding and exposure to a very high concentration of bacteria that occurs during the screening inoculation is probably rare under natural infection conditions.

Environmental conditions can strongly affect leaf scald symptom severity (Rott and Davis 2000). It was uncertain how much environmental conditions would affect bacterial populations in systemic infections, and this was a major consideration in comparing experiments at different times during the growing season and two different seasons. Inoculation resulted in severe symptom development for some cultivars in all three field experiments but the overall analysis indicated that the environment (experiment) had an effect. The first experiment of 2011 and the 2012 experiment were both conducted at the beginning of summer, whereas the second 2011 experiment was done during hotter weather conditions with larger plants. The highest correlations for bacterial populations were found between the early summer experiments at both 8 and 12 WAI. Because environmental conditions can affect $X$. albilineans infection and colonization, a consistent seasonal timing of resistance screening tests would improve reliability.

Sugarcane breeding programs need to be able to accurately determine leaf scald resistance levels in clones during selection. The variable and erratic expression of disease symptoms under natural conditions and following inoculation makes this challenging. Preliminary research demonstrated the potential of quantifying $X$. albilineans populations with qPCR for resistance evaluation (Garces et al. 2014). The results of this study found higher reliability for bacterial quantification compared with rating visual symptom severity with a larger population of clones with variable resistance levels. These results confirm that qPCR can provide an improved method for the evaluation of resistance to leaf scald during screening and resistance studies. Results from $X$. albilineans quantification by qPCR were less erratic than visual symptom severity ratings but not completely consistent for resistant clones. Therefore, multiple experiments will still be needed to accurately determine clone resistance levels to leaf scald by qPCR.

\section{Literature Cited}

Champoiseau, P., Daugrois, J.-H., Girard, J.-C., Royer, M., and Rott, P. C. 2006. Variation in albicidin biosynthesis genes and in pathogenicity of Xanthomonas albilineans, the sugarcane leaf scald pathogen. Phytopathology 96:33-45.

Davis, M. J., Rott, P., Baudin, P., and Dean, J. L. 1994. Evaluation of selective media and immunoassay for detection of Xanthomonas albilineans causal agent of sugarcane leaf scald disease. Plant Dis. 78:78-82.

Davis, M. J., Rott, P., Warmuth, C. J., Chatenet, M., and Baudin, P. 1997. Intraspecific genomic variation within Xanthomonas albilineans, the sugarcane leaf scald pathogen. Phytopathology 87:316-324.

Garces, F. F., Gutierrez, A., and Hoy, J. W. 2014. Detection and quantification of Xanthomonas albilineans by qPCR and potential characterization of sugarcane resistance to leaf scald. Plant Dis. 98:121-126.

Hoy, J. W., and Grisham, M. P. 1994. Sugarcane leaf scald distribution, symptomatology, and effect on yield in Louisiana. Plant Dis. 78:1083-1087.

Jacobs, J. L., Fasi, A. C., Ramette, A., Smith, J. J., Hammerschmidt, R., and Sundin, G. W. 2008. Species abundance and diversity of Burkholderia cepacia complex in the environment. Appl. Environ. Microbiol. 74:3121-3129.

Koike, H. 1965. Aluminum-cap method for testing sugarcane varieties against leaf scald disease. Phytopathology 55:317-319.

Ricaud, C., and Ryan, C. C. 1989. Leaf scald. Pages 39-58 in: Diseases of Sugarcane. Major Diseases. C. Ricaud, B. T. Egan, A. G. Gillaspie, Jr., and C. G. Hughes, eds. Elsevier Science Publishers B.V., Amsterdam. 
Rott, P., Abel, M., Soupa, D., Feldman, P., and Letourmy, P. 1994. Population dynamics of Xanthomonas albilineans in sugarcane plants as determined with an antibiotic resistant mutant. Plant Dis. 78:241-247.

Rott, P., and Davis, M. J. 2000. Leaf scald. Pages 38-44 in: A Guide to Sugarcane Diseases. P. Rott, R. A. Bailey, J. C. Comstock, B. J. Croft, and A. S. Saumtally, eds. CIRAD-ISSCT, Paris.

Rott, P., Mohamed, I. S., Klett, P., Soupa, D., de Saint-Albin, A., Feldmann, P., and Letourmy, P. 1997. Resistance to leaf scald disease is associated with limited colonization of sugarcane and wild relatives by Xanthomonas albilineans. Phytopathology 87:1202-1213.
Royer, M., Costet, L., Vivien, E., Bes, M., Cousin, A., Damais, A., Peretti, L., Savain, A., Megessier, S., Viard, M., Frutos, R., Gabriel, D. W., and Rott, P. C. 2004. Albicidin pathotoxin produced by Xanthomonas alibilineans is encoded by three large PKS and NRPS genes present in a gene cluster also containing several putative modifying, regulatory, and resistance genes. Mol Plant-Microbe Interact. 17:414-427.

Saumtally, A. S., and Dookun, A. 2004. Leaf scald of sugarcane: A disease of worldwide importance. Pages 65-76 in: Sugarcane Pathology. Volume III: Bacterial and Nematode Diseases. G. P. Rao, A. S. Saumtally, and P. Rott, eds. Science Publisher, Inc., Enfield, NH. 